\title{
Meningoencephalitis in a patient with acute Chagas disease in the Brazilian Amazon
}

\author{
Meningoencefalite em paciente com doença de Chagas \\ aguda na Amazônia Brasileira
}

\section{Maurício Borborema de Medeiros ${ }^{1}$, Jorge Augusto de Oliveira Guerra ${ }^{1,2}$ and Marcus Vinícius Guimarães de Lacerda ${ }^{1,2,3}$}

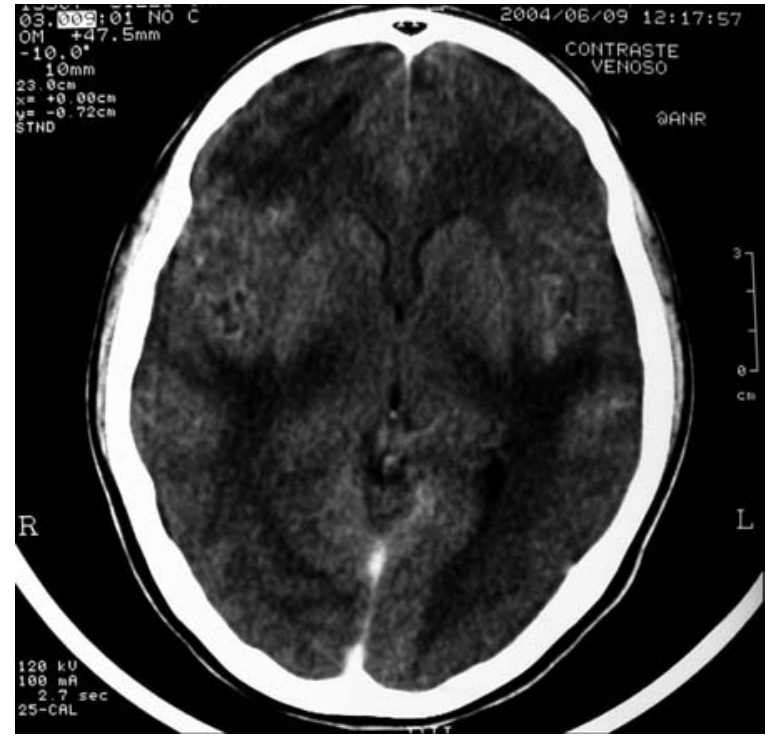

A

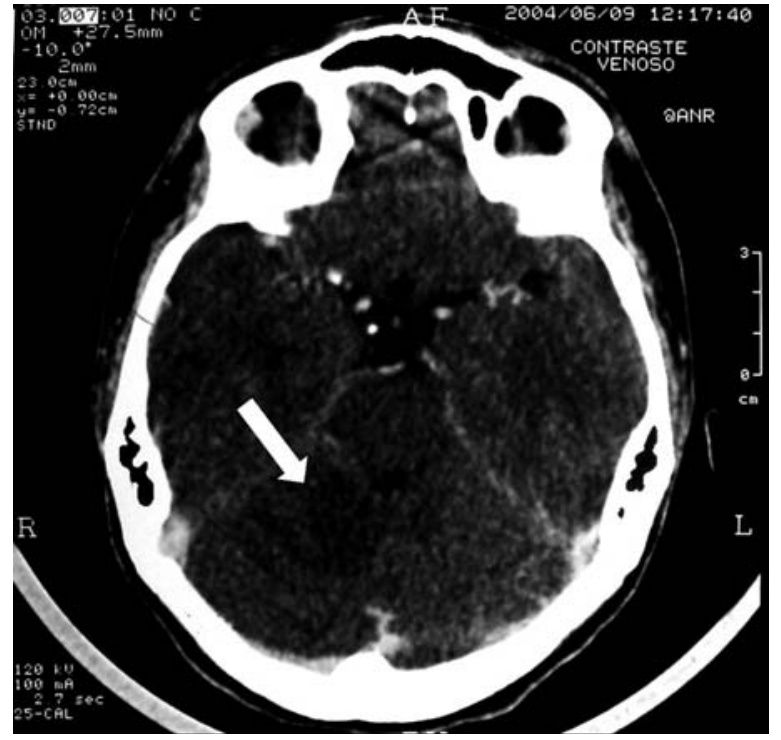

B

1. Fundação de Medicina Tropical do Amazonas, Manaus, AM. 2. Universidade do Estado do Amazonas, Manaus, AM. 3. Centro Universitário Nilton Lins, Manaus, AM. Address to: Dr. Marcus Vinícius Guimarães de Lacerda. FMT-AM. Av. Pedro Teixeira 25, Bairro Dom Pedro, 69040-000 Manaus, AM. Telefax: $55923656-0620$

e-mail: marcuslacerda@uol.com.br

Recebido para publicação em 24/06/2008

Aceito em 04/09/2008 
A 16-year-old female patient from Tefé (State of Amazonas) started with acute febrile syndrome on May 15, 2004. Fifteen days later, a thick blood smear test for malaria detected Trypanosoma cruzi trypomastigotes in peripheral blood. Concomitantly, eight individuals with whom this patient had been in contact were diagnosed as acute cases of Chagas disease, possibly due to oral contamination following consumption of açai wine (Euterpe oleracea). The patient was hospitalized and her condition evolved over the next 24 hours, with progressive weakening of lower limb muscle strength, worsening headache and torpor. She was transferred to a tertiary care hospital in Manaus, presenting deviation of the labial commissure to the right, meningismus and ataxic gait. Blood analysis showed lymphocytosis and the blood biochemistry was normal. Cerebrospinal fluid analysis showed 52 mononuclear cells, with a protein concentration of $186 \mathrm{mg} / \mathrm{dl}$ and glucose of $35 \mathrm{mg} / \mathrm{dl}$. Direct investigation of Trypanosoma cruzi in the cerebrospinal fluid was negative. Contrasted computed tomography of the brain showed cerebral edema secondary to scattered hypodense lesions in the right frontal and temporal lobes and left parietal and temporal lobes (Figure A) and in the right cerebellum (Figure B). Chest X-ray was normal. EKG showed right branch blockage and echocardiogram was normal. Specific treatment with oral benznidazole $(10 \mathrm{mg} / \mathrm{kg} / \mathrm{day}$, for 60 days) and empirical treatment for intracranial hypertension with intravenous dexamethasone $(0.15 \mathrm{mg} / \mathrm{kg} /$ day, for 3 days $)$ were begun. The patient was discharged after 20 days. Serology (IIF) and xenodiagnosis for Chagas disease were positive and serology for HIV was negative. Clinical follow-up one year later showed complete remission of the symptoms, with persistence of the cardiac arrhythmia. Chagas disease meningoencephalitis is rarely reported in the literature, and is associated with immunosuppressive diseases in $50 \%$ of the cases. Neurological impairment is generally associated with cardiac complications that are almost always fatal, which was not observed in this case, in which treatment was instituted rapidly. Because of the recent increases in the number of cases of acute Chagas disease in the Amazon region, it is important to consider this disease in the differential diagnosis of acute febrile neurological syndromes in this region.

A paciente de 16 anos, procedente de Tefé (Estado do Amazonas), iniciou em 15/05/04 com síndrome febril aguda. Quinze dias depois, ao realizar exame de gota espessa para malária, foi detectada a presença de tripomastigotas de Trypanosoma cruzi no sangue periférico. Na mesma época, outros oito contatos da paciente receberam o diagnóstico de doença de Chagas aguda, por possível contaminação oral após ingestão de vinho de açaí (Euterpe oleracea). A paciente foi hospitalizada, evoluindo após 24 horas com diminuição progressiva da força muscular nos membros inferiores, piora da cefaléia e torpor. Foi transferida para hospital de atenção terciária, em Manaus, apresentando desvio da comissura labial para a direita, meningismo e marcha atáxica. 0 hemograma mostrava linfocitose e a bioquímica do sangue era normal. A análise do líquor evidenciou 52 células mononucleares, com $186 \mathrm{mg} / \mathrm{dL}$ de proteínas e $35 \mathrm{mg} / \mathrm{dL}$ de glicose. A pesquisa direta de Trypanosoma cruzi no líquor foi negativa. A tomografia computadorizada de crânio contrastada mostrou edema cerebral secundário a lesões hipodensas dispersas nos lobos frontal e temporal direitos, parietal e temporal à esquerda (Figura A) e no cerebelo à direita (Figura B). Radiografia de tórax normal. O ECG mostrou bloqueio de ramo direito e o ecocardiograma foi normal. Iniciou-se tratamento específico com benzonidazol oral $(10 \mathrm{mg} / \mathrm{kg} / \mathrm{dia}$, por 60 dias $)$ e tratamento empírico para hipertensão intracraniana com dexametasona intravenosa $(0,15 \mathrm{mg} / \mathrm{kg} / \mathrm{dia}$, por 3 dias $)$. A paciente recebeu alta após 20 dias. A sorologia (IFI) e o xenodiagnóstico para doença de Chagas foram positivos e a sorologia para HIV foi negativa. 0 seguimento clínico após um ano evidenciou completa remissão dos sintomas, com persistência da arritmia cardíaca. A meningoencefalite da doença de Chagas é raramente relatada na literatura, estando associada a doenças imunossupressoras em 50\% dos casos. 0 comprometimento neurológico está geralmente associado a complicações cardíacas, de evolução quase sempre fatal, o que não se observou neste caso, em que a terapêutica foi iniciada rapidamente. Em função do recente aumento de casos de doença de Chagas aguda na Amazônia, é importante considerar esta doença no diagnóstico diferencial de síndromes febris neurológicas agudas na região.

\section{REFERENCES}

1. Coura JR, Junqueira AC, Fernandes 0, Valente SA, Miles MA. Emerging Chagas disease in Amazonian Brazil. Trends in Parasitology 18:171-176, 2002.

2. Dantas-Maia TO, Castro C, Ostermayer AL, Macedo V. Seroprevalence of American trypanosomiasis in adults in an area of the western Brazilian Amazon region. Revista da Sociedade Brasileira de Medicina Tropical 40:436-442, 2007.

3. Lazo JE, Meneses AC, Rocha A, Frenkel JK, Marquez J0, Chapadeiro E, Lopes ER. Toxoplasmic and chagasic meningoencephalitis in patients with human immunodeficiency virus infection: anatomopathologic and tomographic differential diagnosis. Revista da Sociedade Brasileira de Medicina Tropical 31:163-171, 1998. 